\title{
The Moroccan Mediterranean Coastline: A Potential Threatened by the Urban Discharges
}

\author{
H. Er-Raioui*, S. Khannous, M. Ould Mohamed Cheihk, M. Mhamada and S. Bouzid \\ Equipe " Géosciences et Environnement» - Département des Sciences de la Terre - Faculté des Sciences et Techniques \\ à Tanger - Ancienne route de l'aviation, BP. 416, Tanger, Maroc
}

\begin{abstract}
The Mediterranean coastline of Morocco is an exceptional and ecologically fragile marine area. It is characterized by a large diversity of living aquatic resources, and subjected to pollution, originated by industrial activities, domestic discharges, coastal touristic installations, etc., drown through drainage channels, emissaries, rivers, etc. The impact of this pollution on the hydraulic network and consequently on the coast, is harmful and may involve water quality degradation. The pollutant discharges to the Mediterranean coast is very high. The effluents generated by Tangier sea port and iseveral rivers such as Mghogha, Souani, Lihoud, F'nideq, and Martil can be considered as important pollution sources based on its anoxic and reductive potential, the low dissolved oxygen contents and high oxydable matter rates.
\end{abstract}

The performed study showed that Tangier and Tetouan marine areas are the two highest affected areas in the Mediterranean coastline of Morocco. More than 232 tons/day ( $t / d)$ of SS are discharged in their coast. The total oxydable matters drained to the sea exceed $100 \mathrm{t} / \mathrm{d}$. The total hydrocarbons spilled in coast is estimated to be higher than $5.15 \mathrm{~kg} / \mathrm{d}$. Metal pollution is also important and caused by high load of, among others, lead, cadmium, chromium, and nickel, exceeding the standards in some locations. Daily drained quantities of these heavy metals to the coast are estimated to be $23.15 \mathrm{~kg} / \mathrm{d}$ for $\mathrm{Pb}, 12.65 \mathrm{~kg} / \mathrm{d}$ for Cd, $10.85 \mathrm{~kg} / \mathrm{d}$ for $\mathrm{Cr}, 17.45 \mathrm{~kg} / \mathrm{d}$ for Ni, $21.50 \mathrm{~kg} / \mathrm{d}$ for Cu and $47.50 \mathrm{~kg} / \mathrm{d}$ for Zn. This situation could be related to the importance of size of Tangier and Tetouan cities; which together represent about $75 \%$ of the total population of Moroccan Mediterranean coastline, and contain more than $75 \%$ of the industrial facilities. These two cities generate a total wastewater volume of $130,500 \mathrm{~m}^{3} / \mathrm{d}$, representing about $70 \%$ of the total wastewater volume produced by all the Moroccan Mediterranean cities.

The situation becomes more critical if we consider the important occurrence of commercial traffic. Impacts are potentially related with deterioration of coastal degradation, of the quality of its resources. In view to preserve the marine environment and to ensure the sustainability of its natural health, Morocco is trying hard to translate gradually its international commitments in national legislation level. This effort is further required that these engagements have involved in specific programs participation, particularly in the Mediterranean. These programs often result in the implementation of resolutions or recommendations targeted to complete a rigorous policy of sustainable development of marine coastal environment.

Keywords: Moroccan Mediterranean coastline, degradation of water quality, organic charge, hydrocarbons and heavy metals, protection measures.

\section{INTRODUCTION}

Water quality degradation caused by pollution began to emerge in some areas long time ago. However, the problem started to become more critical during this late century, especially with high development of the industry sector, rapid population growth, coastal land usage development, and urbanization [1]. Moreover, most of the rivers close to urban areas in developing countries are used as channels of industrial effluents discharges [2]. Nowadays, it is on the coastal parts and especially near great industrial concentrations that marine waters show the most worrying forms of degradation. The Mediterranean which accounts $1 \%$ of the world ocean surface, corresponds to an interior vast sea [3]

*Address correspondence to this author at the Equipe «Géosciences et Environnement»-Département des Sciences de la Terre - Faculté des Sciences et Techniques à Tanger - Ancienne route de l'aviation, BP. 416, Tanger, Maroc; Tél: (00212) 393939 54; Fax: (00212) 0393939 53; E-mail: h.erraioui@fstt.ac.ma that represents a fragile and vulnerable ecosystem and a semi-enclosed sea where waters are slowly renewed (15 years for deep waters) [4]. The water renewal flow is significantly hampered by Gibraltar Strait. Such low water exchange and closure state aggravate impacts of a rapidly expanding population.

The Mediterranean Sea is particularly sensitive to pollution resulting from the intense economic activities that include commercial ships traffic of large volumes and varied coastal industries. It constitutes the first touristic destination in the world and is under very high socio-economical development pressure. The urban explosion and the high concentration of the population generated by the activities of tourism have fatal consequences on the environmental protection and biodiversity. The urbanization average in Mediterranean cities is nowadays of $64.3 \%$ [5]. The situation is particularly dangerous considering the great commercial traffic. Each year, many millions of tons of hydrocarbons 
across the Mediterranean and the events frequency in the sea is approximately 60 per year [6].

The Moroccan Mediterranean coastline is an economically rich and ecologically fragile ecosystem. It constitutes a reproductive and living area for a multitude of vegetable and animal species. With its $512 \mathrm{~km}$ coasts, it is characterized by a significant marine biodiversity, including a large quantity of specific species. The pelagic resources show variable concentrations and consist mainly in Sardine, Anchovy, Mackerel, Horse-mackerel, Swordfishes and Bluefin tuna. While demersal resources are represented by mullet, hake, bug, Calmar, Prawn, Langoustine and Crawfish [7].

It comprises great seaside resorts and several rivers mouths. The late constitute often discharge places and thus interfaces between continental water and marine water, currently showing varied forms of pollution. Those rivers are characterized by a great variation of their water input regime during the year and are depending on precipitations which are highly irregulars between months and years. During dry seasons, water input of these rivers is less important and mainly composed by urban and industrial discharges including lixiviates.

The most exposed zones are incontestably those located along the strait of Gibraltar and near the great coastal cities. Harbors of Tangier, M'Diq and Nador constitute important sources of pollution, particularly with their industrial discharges.

The water pollution sources are multiple and constitute a key problem in Morocco, raising much in the irrigated areas and zones of great economic activities (1). The volume of wastewater was estimated in Morocco at 500 million $\mathrm{m}^{3}$ for the year 2000 and is expected to reach 700 million $\mathrm{m}^{3}$ in 2020 , of which $74 \%$ are discharged at the sewerage systems [8]. The main pollutants sources are:

- $\quad$ Industrial facilities mainly concentrated in and around big cities: Among these industries, some are recognized to be highly polluting. Two types of industries could be distinguished: (1) those whose discharges are primarily organic like sugar refinery and oil factory and (2) those whose discharges contain toxic elements such as tanneries factory, industries of surface treatment and textile industries. Discharges correspond to ordinary organic substances, organic synthesis, petroleum, minerals, heavy metals, polychlorinated biphenyls (PCBs), chlorides, sulphates, cyanides, and arsenic salts.

- Harmful compounds introduced into aquatic environment by agricultural activities such as nitrates, phosphates, pesticides and organic matter.

- Domestic pollutants like wastewater, containing essentially organic pollution (organic matter, detergents, solvents, antibiotics, micro-organisms, etc).

Table 1 provides a detailed list of the most important contaminants present in wastewater [9].

In Morocco's Mediterranean coastline, industrial activities are numerous. They are composed of textile sector $(32 \%)$, food-processing industry $(24 \%)$, metal industry $(19 \%)$ and chemical industry (7\%). The rest corresponds to activities of leather, plastic, paper mill, materials quarry and others. Agriculture activities are mainly developed in small scale farming exploitations producing generally for their own subsistence. The urban explosion is such that there is a decline of rurality across the Mediterranean.

The cities concentrate the two-thirds of the population. The daily average production of solid waste in great urban centres increases in quantity and diversity. Currently, it is $0.7 \mathrm{~kg}$ per capita. $20 \%$ of these wastes are industrial and the remainder is composed of domestic products, hospital products, slaughterhouses trade discharges and road wastes. The impact of these industrial activities, domestic dis-

Table 1. Important Contaminants of Concern in Wastewater (Adapted from Metcalf and Eddy [9])

\begin{tabular}{|c|c|}
\hline Contaminants & Reason for Importance \\
\hline $\begin{array}{l}\text { Oxygen } \\
\text { consuming } \\
\text { organic matter }\end{array}$ & $\begin{array}{l}\text { Composed principally of proteins, carbohydrates, and fats, biodegradable organics are measured most commonly in terms of BOD } \\
\text { (biochemical oxygen demand) and COD (chemical oxygen demand.) If discharged untreated to the environment, their biological } \\
\text { stabilization can lead to the depletion of natural oxygen resources and to the development of septic conditions. }\end{array}$ \\
\hline Suspended solids & $\begin{array}{c}\text { Suspended solids can lead to the development of sludge deposits and anaerobic conditions when untreated wastewater is discharged in } \\
\text { the aquatic environment. }\end{array}$ \\
\hline Nutrients & $\begin{array}{l}\text { Both nitrogen and phosphorus, along with carbon, are essential nutrients for growth. When discharged to the aquatic environment, } \\
\text { these nutrients can lead to the growth of undesirable aquatic life. When discharged in excessive amounts on land, they can also lead to } \\
\text { the pollution of groundwater. }\end{array}$ \\
\hline Priority pollutants & $\begin{array}{l}\text { Organic and inorganic compounds selected on the basis of their known or suspected carcinogenicity, mutagenicity, teratogenicity, or } \\
\text { high acute toxicity. Many of these compounds are found in wastewater. }\end{array}$ \\
\hline $\begin{array}{l}\text { Refractory } \\
\text { organics }\end{array}$ & $\begin{array}{c}\text { These organics tend to resist conventional methods of wastewater treatment. Typical examples include surfactants, phenols, and } \\
\text { agricultural pesticides. }\end{array}$ \\
\hline Heavy metals & $\begin{array}{l}\text { Heavy metals are usually added to wastewater from commercial and industrial activities and may have to be removed if the wastewater } \\
\text { is to be reused. }\end{array}$ \\
\hline Pathogens & Communicable diseases can be transmitted by the pathogenic organisms in wastewater. \\
\hline $\begin{array}{l}\text { Dissolved } \\
\text { inorganics }\end{array}$ & $\begin{array}{l}\text { Inorganic constituents such as calcium, sodium, and sulphite are added to the original domestic water supply as a result of water use } \\
\text { and may have to be removed if the wastewater is to be reused. }\end{array}$ \\
\hline
\end{tabular}




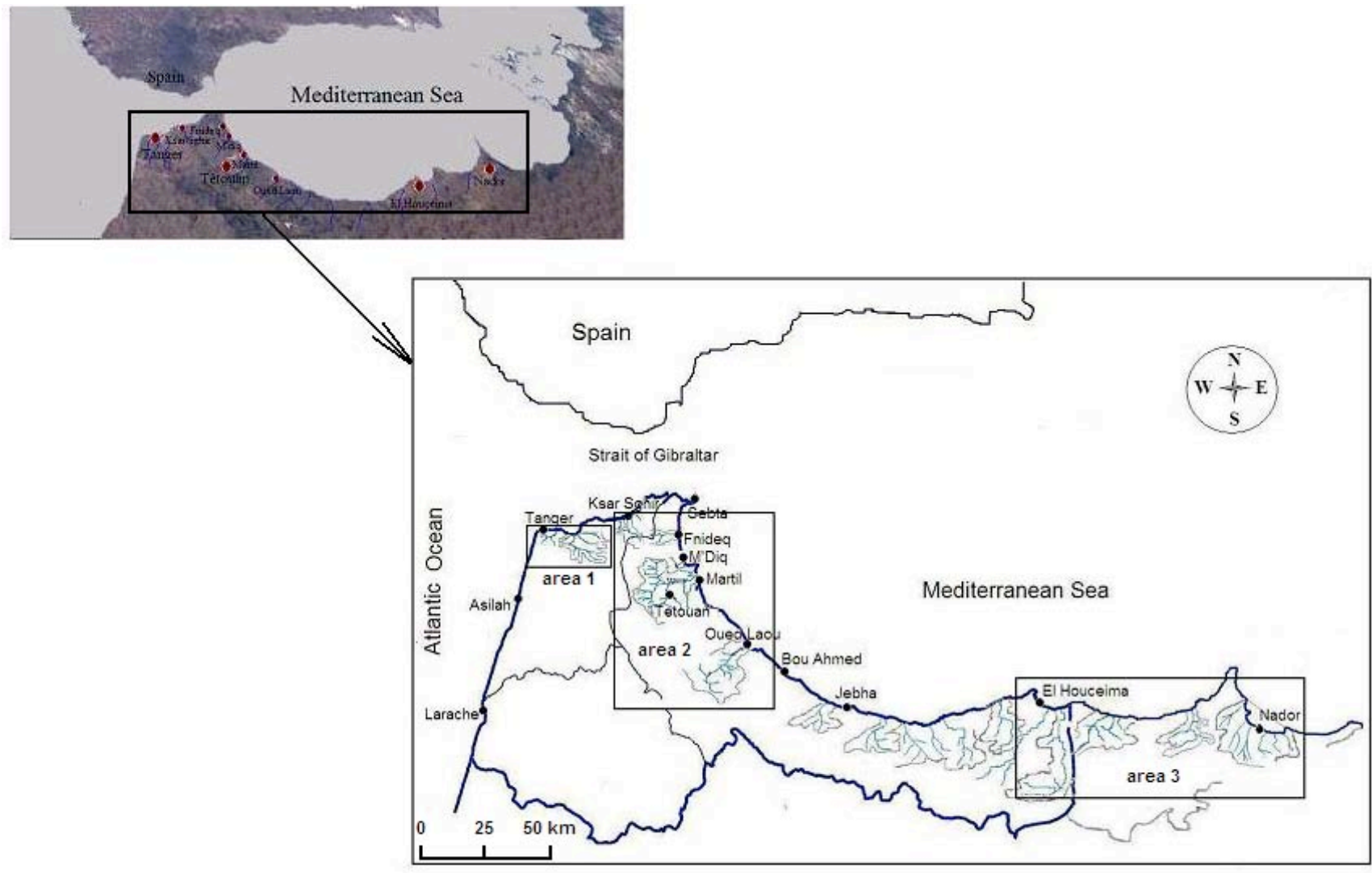

Fig. (1). Study Area. The Moroccan Mediterranean coasts.

charges, coastal installations and touristic centres on the hydraulic network and consequently on the marine water is harmful and involves the degradation of water quality [10].

Pollution is manifested by a microbial contamination, heavy metals and hydrocarbons enrichment, eutrophication which causes anoxia, development of harmful algal bloom, etc. Moreover, rubbish tips generate also pollution through lixiviates representing $10 \%$ of tipping amounts unloaded outside the rainy season. Parallel to this continental pollution origin, marine environment is subjected to other aggressions of marine pollution origin, generated by navigation and harbours activities. To characterize this anthropogenic pollution and estimate its effects on Mediterranean coastline of Morocco, the present study is aimed to assess physicochemical and geochemical characterization of urban discharges including lixiviate produced by rubbish tips and to evaluate contamination generated by important coastal agglomerations (Fig. 1). This was done through estimations of oxydable matter, heavy metals and hydrocarbons flows drained by the urban sprawl the Moroccan Mediterranean coastline. The study is carried out in Tangier, Ksar Sghir, F'nideq, M'diq, Tétouan, River laou, Al Hoceima and Nador which constitute the principal sources of pollution in the Mediterranean coast of Morocco. Sewerage systems of these agglomerations form a transport system of the effluents and constitute physicochemical reactor which conditions the quality of the effluents [11]. Like most of coastal areas, these agglomerations do not escape to the constraints of development and progress which cannot be done without threatening the stability and the healthiness of the environment, particularly the watery systems and its resources.
In the present work, we have characterized the urban effluents of principal emissaries of the studied zone (from Tangier to Nador), both physico-chemically and geochemically, and the data obtained have been used to determine the pollution flow discharges drained toward the littoral through oxydable matters (OM), heavy metals and hydrocarbons (HC).

\section{MATERIALS AND METHODOLOGY}

\subsection{Sampling and Variables}

Initially, weekly sampling campaigns were carried out from April to July 2000 for wastewater, and during July 2000 for sediments, out of the rainy period to avoid eventual dilution of sewages feeding the gutter drainage. Besides, wastewater samples were also taken during the following years 2001, 2004, 2005, 2006 and 2008, to fulfill the study, using the same sampling strategy as in 2000. Wastewater samples were taken from the middle of the rivers whereas sediment samples were taken from the accumulation zones (Fig. 2). Wastewater samples collected at river mouths were considered as a mixture of all kind of dismissals, domestic and industrial wastes as well as lixiviates from rubbish tips. In Tangier and M'Diq harbours, wastewater samples were taken in the administrative and industrial areas of the ports. Sediment samples were taken from different points along the canals from accumulation zones of calm sedimentation and fine sediments abundance. The urban effluents are relatively constant in quantity and quality. Sampling points of water and sediment were selected taking into account the distance to industrial and urban discharge's points (Fig. 2). 

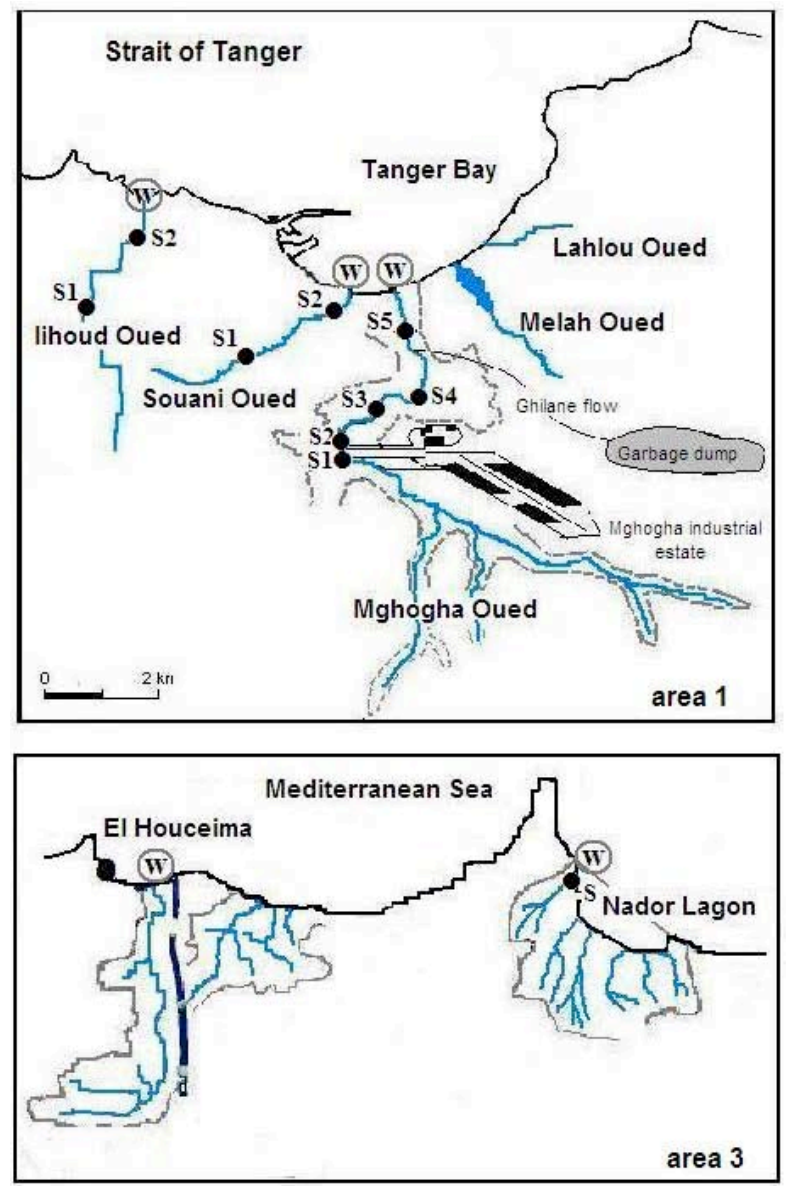
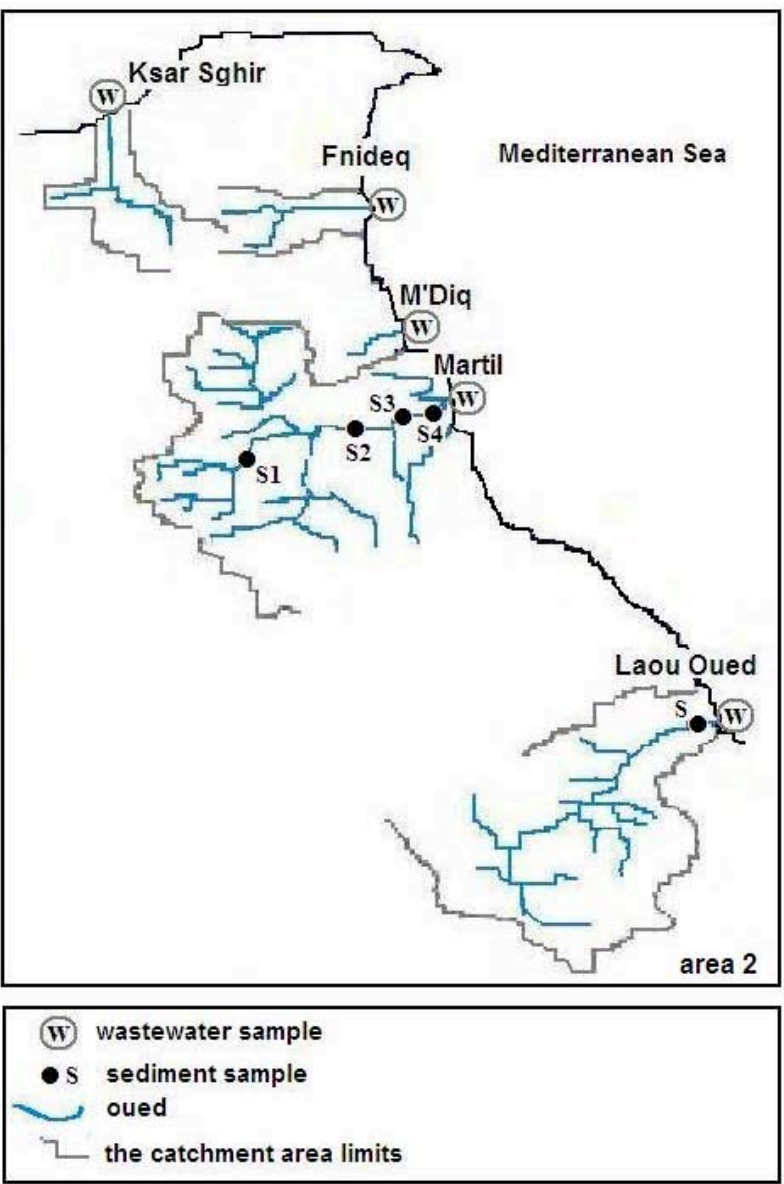

Fig. (2). Location of the sampling sites on the Moroccan Mediterranean coasts.

Water sampling was manually done using glass bottles previously cleaned according to Rodier process and placed in an icebox at $4^{\circ} \mathrm{C}$ in order to reduce the risks of precipitation, adsorption, contamination or evaporation [12]. $500 \mathrm{ml}$ of unfiltered water were collected for analysis of heavy metals and acidified with $1 \mathrm{ml}$ of nitric acid ultra pure (Merk). After that, we analyzed Suspended Matters (SS), dissolved oxygen (DO), Biochemical Oxygen Demand measured at 5h (BOD), Chemical Oxygen Demand (COD), $\mathrm{Ca}^{2+}, \mathrm{Na}^{+}, \mathrm{K}^{+}, \mathrm{Mg}^{2+}$, chlorides, sulfates, nitrates, nitrites, hydrocarbons, and heavy metals $(\mathrm{Pb}, \mathrm{Cu}, \mathrm{Zn}, \mathrm{Cd}, \mathrm{Cr}$ and $\mathrm{Ni})$.

Sediment samples $(0-5 \mathrm{~cm})$ were collected from the accumulation zone using a PVC tube of $75 \mathrm{~mm}$ of diameter. Samples were oven dried, homogenized and sealed in clean polythene bags and than stored in a refrigerator. In each sample, we analyzed Total Organic Carbon (TOC) and hydrocarbons.

\subsection{Apparatus}

Temperature, $\mathrm{pH}, \mathrm{DO}$ and Electrical conductivity (EC) were measured in-situ, using a multi-parameter device. Suspended matter was determined by filtration of a known volume of water sample. The measure of the Biochemical Demand in Oxygen is achieved using a respirometric apparatus (respirometric system of SIERP), which quantify the oxygen produced to re-establish the initial pressure. COD was determined by oxidization with potassium dichromate in acidic medium and in the presence of silver sulphate and mercury [12]. TOC was measured by the Leco device.

Trace metals, as well as $\mathrm{Ca}^{2+}, \mathrm{Na}^{+}, \mathrm{K}^{+}$and $\mathrm{Mg}^{2+}$ were analyzed by ICP-AES (Inductively Coupled Plasma Atomic Emission Spectroscopy), model "Ultima 2" (Jobin Yvon, France). The accuracy and quality of quantitative determinations of these elements were verified by the use of standards corresponding to Precise Mono elements of 1000 $\mathrm{ppm}$. The measurements were done at technical support unit to scientific research (UATRS) of the National Centre of Scientific and Technical Researches (CNRST) in RabatMorocco. Chlorides, sulfates, nitrates and nitrites were determined by reflectometry.

\subsection{Sample Treatment}

For non-filtered waters, a liquid-liquid extraction of a 10 L-sample with chloroform was adopted. The extraction of hydrocarbons was done by a Soxhlet extractor for sediments $(8 \mathrm{~h})$ which is a certified method. For sediments, $5 \mathrm{~g}$ of sample, previously freeze-dried since it was brought to laboratory, blended and homogenized, were extracted with hexane/dichloromethane (v:v). A purification stage on amalgam column, washed by acetone, was carried out to eliminate sulfur. The extracted samples were doped by two internal standards (C18 and 9, 10 dihydroanthracene), in order to calculate the extraction efficiency and to correct the loss that may take place throughout the analysis. 
Extracts were purified and separated into non aromatic hydrocarbons (NAH) and polycyclic aromatic hydrocarbons (PAH) fractions, by chromatography column on neutral silica for sediments and waters. The silica, previously cleaned with hexane/dichloromethane (1:1) for $8 \mathrm{~h}$ and dried, was reactivated at $150{ }^{\circ} \mathrm{C}$ during $1 \mathrm{~h}$ and partially deactivated with $5 \%$ of water. Evaporation was carried out with $35{ }^{\circ} \mathrm{C}$ in the rotavapor. The chromatography column was prepared with $0.4 \mathrm{~g}$ of silica (100-200 $\mathrm{mm}$ in mesh), kept in suspension in hexane. The elution was done by hexane $(3 \mathrm{ml})$ then Toluene/dichloromethane $(9: 1 \mathrm{ml})$ respectively for non aromatic hydrocarbons and polycyclic aromatic hydrocarbons. The NAH fraction was analyzed by gas chromatography using chromatograph HP AGILENT 6890 series equipped with a flame ionization detector (FID) and a capillary column $(30 \mathrm{~m} \times 0.25 \mathrm{~mm})$. The limits of quantification were lower than $1 \mathrm{ng} / \mathrm{ml}$ and the background noise was very weak. The column temperature was programmed from $60{ }^{\circ} \mathrm{C}$ to $290{ }^{\circ} \mathrm{C}$ with a heating ratio of $3{ }^{\circ} \mathrm{C} / \mathrm{min}$. The highest temperature $\left(290^{\circ} \mathrm{C}\right)$ was maintained for $15 \mathrm{~min}$. Helium was employed as a carrier gas with a flow-rate of $2 \mathrm{ml} / \mathrm{min}$; whereas nitrogen constituted the make-up. The control of the results quality was made by comparison with a certified referential material provided by the International Atomic Energy Agency (IAEA). Polycyclic aromatic hydrocarbons were measured by spectrofluorimeter at fluorescence waves (Perkin Elmer L. S30 type).

\subsection{Statistics}

For statistical data analysis, ANOVA or Kruskal-Wallis tests was applied to analyze the significant differences among sampling stations for different parameters levels. Pearson correlation matrix was also calculated for different parameters to determine the common sources of pollutants. Regression coefficient was calculated between different concentrations in wastewater, and Principal Component Analysis was used as a classification tool. SPSS statistical package was used for data analysis. All statements reported in this study are made at $\mathrm{P}<0.05$ levels.

\section{RESULTS}

The physicochemical, biochemical and geochemical analysis of wastewater samples (24 samples per site) and sediments $(5,2,2,4,1$ and 1 samples respectively for Mghogha, Souani, Lihoud, Martil and Laou rivers and Nador lagoon) taken from different effluents, reveal that the pollution flow, released into sea by important agglomerations, is of critical importance. Unfortunately, all these loaded waters are transported to the coast through numerous river mouths without preliminary treatment or with inadequate treatment. The data measured are reported in Tables 2, 3 and 4. In the absence of significant variations in time, the results are expressed as mean values, calculated from the data obtained for different years. The heavy metals results dealing with Souani, and Lihoud rivers were taken from Blind's work [13] while whose relating to Nador lagoon correspond to Bloundi's work [14].

\subsection{Physico-Chemical Variables}

The liquid discharges showed temperatures oscillating between 15 and $25^{\circ} \mathrm{C}$, largely depending on climate and air temperature. The $\mathrm{pH}$ values were relatively normal (7-8.5) and do not constitute any threat to the ecosystems. On the other hand, SS results proved that the different effluents drain a considerable load that varies between 50 and $3535 \mathrm{mg} / \mathrm{L}$ and exceeds $1000 \mathrm{mg} / \mathrm{L}$ in the important agglomerations. At the Mghogha, Souani, Lihoud and Martil river mouths, the recorded values are the most important with $2495,2015,1350$ and $3535 \mathrm{mg} / \mathrm{L}$ respectively (Table 2 ). The measurement of EC, which provides information on the global mineralization degree of surface waters, shows high values at the two principal effluents of the studied area (Mghogha and Martil rivers). Their averages are 65000 and $20000 \mu \mathrm{s} / \mathrm{cm}$, respectively. They correspond to $2650 \mu \mathrm{s} / \mathrm{cm}$

Table 2. Biochemical and Geochemical Data of Water Samples from Harbors and the Most Important Effluent of the Moroccan Mediterranean Coasts, SS: Suspended Matters, DO: Dissolved Oxygen, BDO: Biochemical Demand in Oxygen and CDO: Chemical Demand in Oxygen, OM: Oxydable Matter

\begin{tabular}{|c|c|c|c|c|c|c|}
\hline Samples & SS (mg/l) & DO (mg/l) & BDO (mg/l) & $\operatorname{CDO}(\mathrm{mg} / \mathrm{l})$ & OM (mg/l) & Volume of Waste Water $\left(\mathrm{m}^{3} / \mathrm{d}\right)$ \\
\hline Mghogha oued & $2495 \pm 392$ & 1.25 & $200 \pm 45$ & $500 \pm 94$ & $354 \pm 63$ & \multirow{3}{*}{87500} \\
\hline Lihoud oued & $1350 \pm 82$ & 2.15 & $120 \pm 65$ & $395 \pm 74$ & $275 \pm 66$ & \\
\hline Tangier Harbour & $635 \pm 110$ & 2.95 & $190 \pm 20$ & $1050 \pm 135$ & $515 \pm 60$ & \\
\hline F'nideq oued & $365 \pm 29$ & 0 & $300 \pm 94$ & $600 \pm 286$ & $465 \pm 160$ & \multirow{3}{*}{43000} \\
\hline Martil oued & $3535 \pm 433$ & 0.75 & $42.5 \pm 7.5$ & $725 \pm 61$ & $354 \pm 25$ & \\
\hline M'Diq Harbor & - & 10 & 10 & - & - & \\
\hline El Houceima & $50 \pm 20$ & - & $50 \pm 12$ & $85 \pm 41$ & $72,5 \pm 22,25$ & 5300 \\
\hline
\end{tabular}


Table 3. Geochemical Data of Water and Sediment Samples from Harbors and the most Important Effluent of the Moroccan Mediterranean Coasts, TOC: Total Organic Carbon, THC: Total Hydrocarbons and ( $\mathrm{Pb}, \mathrm{Cu}, \mathrm{Zn}, \mathrm{Cd}, \mathrm{Cr}$ and Ni): $\mathrm{Heavy}$ Metals (the Underlined Values are from Blinda [13] and the Values in Bold Type are from Bloundi [14]

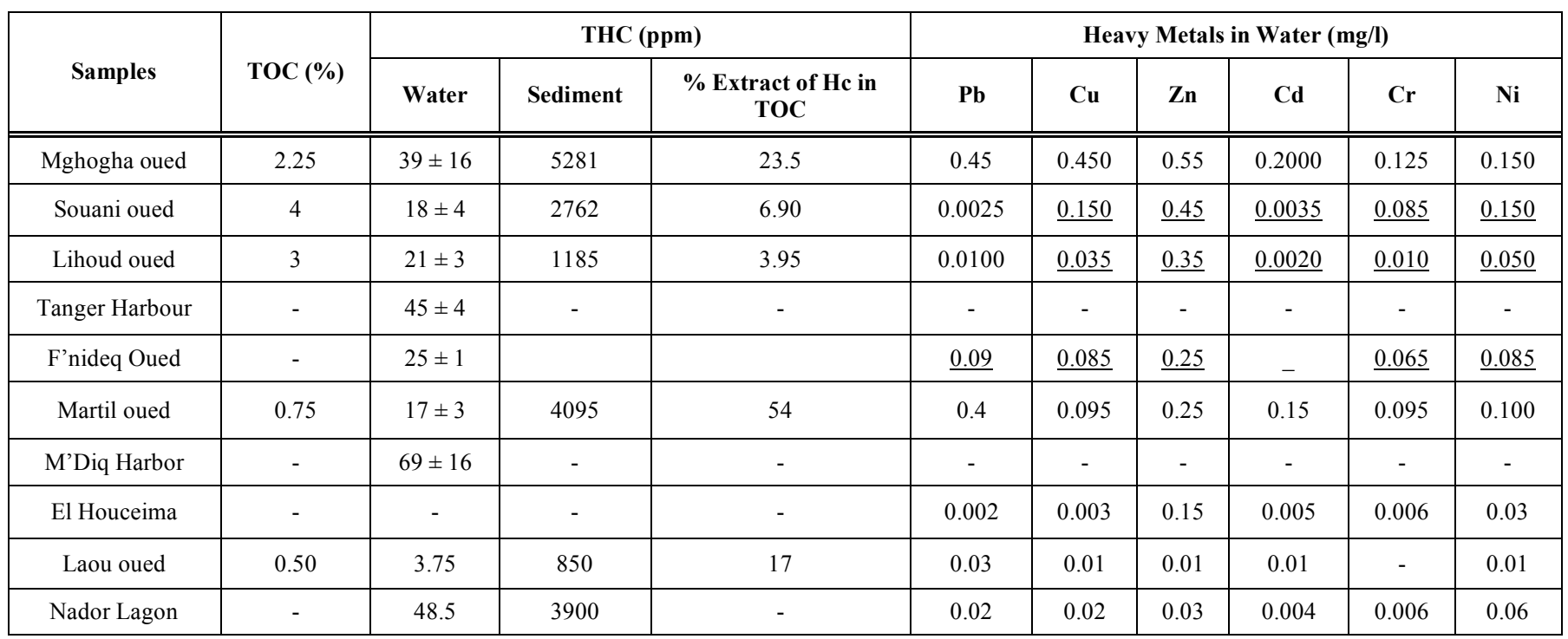

Table 4. Results of the Analyzes of the Ion Balance of Wastewater (Expressed in mg/l) and Moroccan Standards

\begin{tabular}{|c|c|c|c|c|c|c|c|c|c|}
\hline Samples & Electrical Conductivity ( $\mu \mathrm{s} / \mathrm{cm})$ & $\mathrm{Ca}^{2+}$ & $\mathrm{Na}^{+}$ & $\mathbf{K}^{+}$ & $\mathbf{M g}^{2+}$ & Chlorides & Sulphates & Nitrates & Nitrites \\
\hline Mghogha oued & 8500 & 25 & 95 & 5 & 150 & 10000 & 165 & 6.9 & 10 \\
\hline Lihoud oued & 950 & & & & & & 67 & 1.1 & 0.17 \\
\hline Ksar Sghir oued & 615 & & & & & & 48 & 1.4 & 0.02 \\
\hline Martil oued & 5000 & 54 & 13245 & 3432 & 1504 & 20235 & 109 & 0.8 & 0.15 \\
\hline Laou oued & 645 & & & & & & 21 & 1.6 & 0.05 \\
\hline Moroccan maximum value & 2500 & 160 & 200 & 12 & 50 & 200 & 250 & 50 & \\
\hline
\end{tabular}

at Souani river and $950 \mu \mathrm{s} / \mathrm{cm}$ at Lihoud river. In the other sites, conductivity was as low as $50 \mu \mathrm{s} / \mathrm{cm}$.

The determination of DO, BOD, and COD gave us information about the water quality of industrial and urban wastes in different effluents. Those parameters are interrelated with each other in a way that, the total oxygen demand depletes DO, knowing that COD and BOD translate the rate of total oxydable matter. The dissolved oxygen contents, which play a capital role in the maintenance of the aquatic life and for the self-purification, are often low and fluctuate between 0 and $2.95 \mathrm{mg} / \mathrm{L}$, except for Ksar Sghir river, M'Diq harbor and Laou riverwith respective values of 7.5, 10 and $6.5 \mathrm{mg} / \mathrm{L}$. The less oxygenated waters were those of Mghogha, F'nideq and Martil rivers with DO values of 1.25, 0 and $0.75 \mathrm{mg} / \mathrm{L}$, respectively (Table 2 ).

The values of BOD of given water samples seem to be function of the pollution degree. This demand corresponds to the quantity of oxygen consumed during the biological decomposition processes of the organic matters (vegetable or animal) and inorganic matters (sulphide, salts, etc.). The average values measured at different rivers mouths and harbors vary from 10 to $300 \mathrm{mg} / \mathrm{L}$. The most important values are recorded at Mghogha, Souani, Lihoud and F'nideq rivers as well as at Tangier harbor and Nador lagoon. The average values were 200,115, 120,300, 190 and $60 \mathrm{mg} / \mathrm{L}$, respectively (Table $\mathbf{2}$ ).

On the other hand, COD which represent the quantity of consumed oxygen during the chemical decomposition processes of the organic matters, showed values up to $1050 \mathrm{mg} / \mathrm{L}$ on average. The highest values were recorded in Mghogha, Souani, Lihoud, F'nideq, Martil rivers and at Tangier harbour with 500, 350, 395, 725, 600 and $1050 \mathrm{mg} / \mathrm{L}$ respectively.

\subsection{Geochemical Analysis}

TOC, reflecting the accumulated and preserved organic matter rate, was quantified in samples of superficial sediments along the discharging canals. The results obtained, 
expressed in percentage of dry weight (dw) of the fine fraction (lower than $63 \mu \mathrm{m}$ ), showed values ranging from 0.75 to $4 \%$ (Table 3) at Mghogha, Souani, Lihoud and Martil rivers.

The concentrations of major geochemical elements for ion balance are shown in Table 4. The water of the Mghogha and Martil rivers content significant amount of sodium chloride. The concentrations of the ions, expressed in $\mathrm{mg} / \mathrm{L}$, are 13245 and 95 for $\mathrm{Na}^{+}, 1504$ and 150 for $\mathrm{Mg}^{2+}, 54$ and 25 for $\mathrm{Ca}^{2+}, 3432$ and 5 for $\mathrm{K}^{+}$and 20235, 10000 for chlorides, and 25 to 5700 for sulfates, with the highest values being recorded in Mghogha river. For nitrates and nitrites, the values fluctuate from 0.75 to $6.9 \mathrm{mg} / \mathrm{L}$ and 0.15 to $10 \mathrm{mg} / \mathrm{L}$, respectively.

In waters coming from the mouths of the studied rivers and Nador lagoon, the metal traces analyzed and regarded as main toxic elements having a harmful effect on the environment $(\mathrm{Pb}, \mathrm{Zn}, \mathrm{Cu}, \mathrm{Cr}$, Ni and $\mathrm{Cd})$, showed variable concentrations (Table 3). High concentrations of $\mathrm{Pb}$ were measured at Mghogha, Martil and F'nideq rivers, with $0.45,0.40$ and $0.09 \mathrm{mg} / \mathrm{L}$, respectively. In other sites, $\mathrm{Pb}$ values ranged from 0.003 to $0.010 \mathrm{mg} / \mathrm{L}$. Zn concentrations were generally low and fluctuate between 0.01 and $0.55 \mathrm{mg} / \mathrm{L}$. High levels were obtained in Mghogha (0.55 mg/L), Souani (0.45 mg/L), Lihoud (0.35 mg/L), F'nideq $(0.25 \mathrm{mg} / \mathrm{L})$ and Martil $(0.25 \mathrm{mg} / \mathrm{L})$. $\mathrm{Cu}$ showed a maximum concentration of $0.450 \mathrm{mg} / \mathrm{L}$ in the Mghogha river, while $\mathrm{Cr}$ concentrations were also high in Mghogha $(0.125 \mathrm{mg} / \mathrm{L})$, Souani $(0.085 \mathrm{mg} / \mathrm{L}), F^{\prime}$ nideq $(0.065 \mathrm{mg} / \mathrm{L})$ and Martil $(0.095 \mathrm{mg} / \mathrm{L})$. In the rest of locations, the concentrations were less than $0.010 \mathrm{mg} / \mathrm{L}$. For $\mathrm{Ni}$, the highest concentrations were measured in Mghogha, Souani, Lihoud, F'nideq and Martil rivers with values of $0.150,0.150,0.050,0.085$ and $0.100 \mathrm{mg} / \mathrm{L}$. At the other sites, concentrations of $\mathrm{Ni}$ did not exceed $0.01 \mathrm{mg} / \mathrm{L}$. For $\mathrm{Cd}$, the contents recorded at Mghogha, Martil and Laou rivers were quite important in quantity and corresponded to $0.200,0.150,0.100 \mathrm{mg} / \mathrm{L}$ respectively (Table $\mathbf{3}$ ).

Hydrocarbon concentrations extracted from water, found in different studied sites, were important in quantities and varied from 5 to $69 \mathrm{mg} / \mathrm{L}$. The highest contents were recorded in Tangier and M'Diq harbors, Nador lagoon and Mghogha river with 45, 69, 48.5 and $39 \mathrm{mg} / \mathrm{L}$, respectively. At the other sites, total hydrocarbons ranged from 5 to $21 \mathrm{mg} / \mathrm{L}$. In sediment samples collected from rivers mouths, total hydrocarbons are important in quantity, ranging from 1185 to $5281 \mu \mathrm{g} / \mathrm{g} \mathrm{dw}$. The Concentrations expressed in $\mathrm{mg} / \mathrm{g}(\mathrm{dw})$ correspond to 5281 in Mghogha river, 2762.5 in Souani river, 1185 in Lihoud river, 4095 in Martil river and 3900 in Nador lagoon (Table 3).

\subsection{Statistical Analysis}

ANOVA analysis pointed out the absence of temporal variations in the ecosystem studied. From the spatial point of view, the analysis allowed the distinction between two groups. The first group included $\mathrm{Cu}$ and $\mathrm{Cd}$ where the test of variances homogeneity was not significant whereas the second group showed a complete test of variances homogeneity ( $\operatorname{sig}<0.05$ ), involving $\mathrm{Pb}, \mathrm{Zn}, \mathrm{Cr}, \mathrm{Ni}$, and $\mathrm{HC}$. This latter shows a significant spatial variation which was attested by the Tukey's post hoc test that showed a significant variation between the different stations. For $\mathrm{Cu}$ and $\mathrm{Cd}$, the Kruskal-Wallis test showed a significant variation which could be related to the parameters measured at various stations. The Principal Component Analysis (PCA) of the different variables showed that the eigen-values for the first 3 components were higher than 1 (Table 5). This fact allows us to limit the study to the first three components which explained $85.45 \%$ of information. Table 5 showed that all elements are explained by component 1 except for the hydrocarbons which are explained by component 3 . In the case of $\mathrm{Cd}$ the element was explained by the two components 1 and 2. This allows us to choose the bidimensional representation from two components 1 and 2 . Indeed, those latter allow distinguishing between three groups: a group of $\mathrm{OM}, \mathrm{Zn}$ and $\mathrm{Cd}$, a second group that includes the suspended solids and other metals $(\mathrm{Pb}, \mathrm{Cu}, \mathrm{Cr}$ and $\mathrm{Ni}$ ) and a third group related to hydrocarbons. By integrating the sampling sites, analysis of the principal component, which allows to establish the relationship between variables and the sampling points, showed a dispersion of different parameters in all sites except Martil and Mghogha sites and, at lesser extent, Souani site which form the same group with metals, hydrocarbons, suspended solids and oxydable matters, materials (Fig. 3).

Table 5. Factor Loadings for Biochemical and Geochemical Data Concentrations in Water from the Most Important Effluent of the Moroccan Mediterranean Coasts

\begin{tabular}{|c|c|c|c|}
\hline & CP 1 & CP 2 & CP 3 \\
\hline \hline $\mathrm{SS}$ & 0.762 & -0.475 & -0.180 \\
\hline $\mathrm{OM}$ & 0.745 & 0.443 & -0.307 \\
\hline $\mathrm{HC}$ & 0.260 & 0.510 & 0.769 \\
\hline $\mathrm{Pb}$ & 0.810 & 0.013 & -0.162 \\
\hline $\mathrm{Cu}$ & 0.862 & -0.054 & 0.301 \\
\hline $\mathrm{Zn}$ & 0.829 & -0.261 & 0.160 \\
\hline $\mathrm{Cd}$ & 0.655 & 0.631 & -0.385 \\
\hline $\mathrm{Cr}$ & 0.960 & -0.114 & -0.088 \\
\hline $\mathrm{Ni}$ & 0.874 & -0.174 & 0.276 \\
\hline
\end{tabular}

\section{DISCUSSION}

The results obtained are discussed in terms of flux of contaminant load drained by the effluent, expressed in tons per day ( $t / d)$ and compared with Moroccan standards of limits discharges into aquatic environment [15]. These results showed the extent of pollution rejected toward the sea by Moroccan Mediterranean cities. Statistical analysis allowed establishing the existence of significant spatial variations for all parameters: $\mathrm{HC}(\mathrm{F}=22.38, \mathrm{p}<0.5), \mathrm{MO}$ $(\mathrm{F}=17.78, \mathrm{p}<0.5)$, heavy metals $(16.45<\mathrm{F}<21.38, \mathrm{p}<0.5)$. No significant temporal variations were observed.

Characterized by an important organic and mineral load, water of different effluents and harbours of the study area are evacuated into coastal waters through numerous river mouths without preliminary or adequate treatment. The 


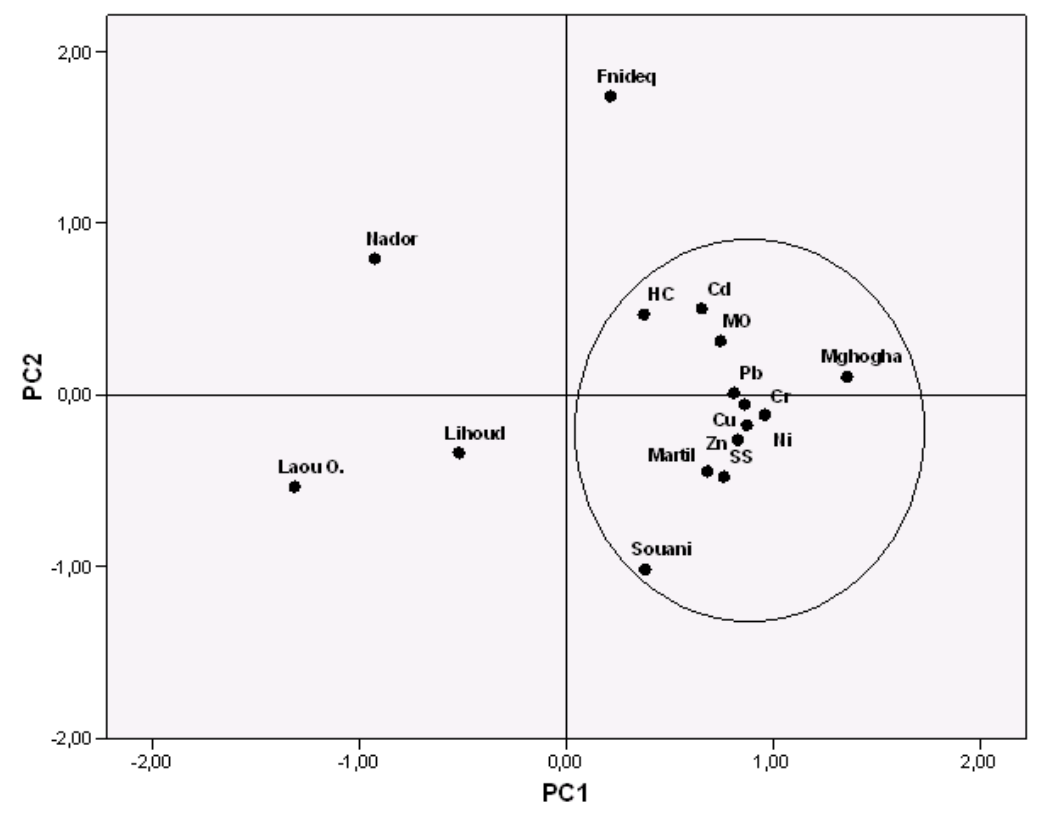

Fig. (3). Principal component analysis (PCA) for biochemical and geochemical data in water collected in locations of the Moroccan Mediterranean coasts.

comparison of physicochemical (BOD, COD, DO, SS) and geochemical results (heavy metals and hydrocarbons), with standards confirms poor water quality.

Wastewaters poured to the coasts present high loads of SS, with quantities higher than the established standards. They range from 0.265 to $142 \mathrm{t} / \mathrm{d}$ and exceed $5 \mathrm{t} / \mathrm{d}$ in important agglomerations. In total, more than $232 \mathrm{t} / \mathrm{d}$ of SS are discharged to coastal waters. Mineral and organic SS are used as support for several chemical pollutants and bacterial mass including pathogenic species. Indeed, the bacterial load calculated in Tangier bay is higher than $10^{5} / \mathrm{ml}$ and contains higher quantities of total and faecal coliforms, more than $10^{3} / 100 \mathrm{ml}$.

The monitoring of bacteriological quality of coastal waters permits to note that some Mediterranean areas are subjected to remarkable contamination, due to leaching of soil caused by heavy rainfall and the accumulation of waste into the sewers, especially during the spring period. SS increase water turbidity and change the physical chemistry of the water column by reducing activities of photosynthesis and consequently the oxygenation of local ecosystem. The typical microbiological composition of domestic wastewater includes $10^{5}-10^{8} \mathrm{CFU}$ coliforms, $10^{3}-10^{4} \mathrm{CFU}$ faecal streptococci, $10^{1}-10^{3}$ protozoan cysts, and $10^{1}-10^{2}$ viruses [9].

The values of EC obtained reflect high mineralization degree of urban water according to the limits established by Nisbet [16]. The salinity rate was very important. A clear correlation appears between the concentrations of major ions responsible for the salinity of sewage and electrical conductivity.

Nitrogen contained in wastewater can be either organic or mineral. The organic nitrogen is mainly constituted by proteins, polypeptides, amino-acids and urea. The mineral nitrogen includes ammonium $\left(\mathrm{NH}_{4}{ }^{+}\right)$, nitrites $\left(\mathrm{NO}_{2}{ }^{-}\right)$and nitrates $\left(\mathrm{NO}_{3}{ }^{-}\right)$and constitutes the major part of total nitrogen [12]. Nitrate concentrations showed a maximum of
$6.95 \mathrm{mg} / \mathrm{L}$ which remains however lower than the standards. The low nitrite concentrations measured in wastewaters could be explained by the fact that $\mathrm{NO}_{2}^{-}$is an intermediate compound, which is unstable in the presence of oxygen and whose concentration is usually much lower than the two other nitrogen forms (nitrate and ammonium ions). These three nitrogen forms are linked each other.

The organic load measured was important in quantity. The Tangier's harbour, Mghogha, Souani, Lihoud, F'nideq, Martil effluents could be considered as pollution sources with anoxic and reductive potential, considering the low dissolved oxygen contents and the high oxydable matter rates. Very aerated water is generally supersaturated with oxygen, whereas water containing degradable organic matter by micro-organisms is under-saturated. Indeed, the presence of organic matter in a stream, for example, allows microorganisms to develop while consuming oxygen. The correlation matrix shows that the $\mathrm{OM}$ and dissolved oxygen values are inversely proportional and thus negatively correlated, with a correlation coefficient of 0.9.

The pollution load was also important in oxydable matter values, fluctuating between $225 \mathrm{mg} / \mathrm{L}$ and $515 \mathrm{mg} / \mathrm{L}$. The wastewater was responsible for the increased oxygen demand, $60 \%$ for toilets water and $40 \%$ for gray water [1719], including the oxygen amount required for nitrification. The limit value is $105 \mathrm{mg} / \mathrm{L}$. The required oxygen quantity for nitrification was significant and could actually exceed the amount of oxygen required to satisfy the BOD. Stoichiometrically, each milligram of ammonia nitrogen $\left(\mathrm{N}^{\left.-\mathrm{NH}_{3}\right)}\right.$ requires $4.57 \mathrm{mg}$ of oxygen to transform it biochemically into nitrate [9]. This can explain the absence of correlation between OM and DO at Mghogha effluent.

Total wastewater oxydable matters, representing the amount of BOD and COD, exceed $100 \mathrm{t} / \mathrm{d}$. The DO rates were also low and fluctuate between 0 and $2.95 \mathrm{mg} / \mathrm{L}$, except for some rivers. This situation reflects a tendency of different 
rivers to anoxia state, which is confirmed by important rates of organic matters accumulation and preservation. Indeed, the TOC contents are important and vary from 0.75 to $4 \%$ of dry weight, which militates in favour of redox conditions, favourable to the accumulation and preservation of organic matter. This high content in organic matter could be explained by the high load of wastewater biodegradable matter which could contain up to $55 \%$ of the total organic matter [20].

Often, there is an increase in concentrations of organic matter from upstream to downstream rivers, normally associated to anthropogenic origin. This organic matter acts as a preferential carrier of trace elements. Indeed, a very close relationship was observed between organic matter and heavy metals concentrations $(\mathrm{Cd}, \mathrm{Pb}, \mathrm{Zn}$ and $\mathrm{Cu})$ in upper layer of sediments [21]. This reflects the important role of organic matter in complexation of heavy metals in sediments $[22,23]$. The concentrations measured in the samples indicate a relatively polluted state in the upper layer of sediments of Souani and Mghogha rivers and consequently their likely considerable impact on the environmental quality of Tangier's bay. PCA confirmed the anthropogenic and natural origins of metals found in the fine fraction [21]. The aerobic degradation reaction of the organic matter and generally the biological balance of aquatic environments are conditioned by the oxygen rate in the ecosystem. In wastewater networks, complete disappearance of organic matter is usually accompanied with appearance of $\mathrm{H}_{2} \mathrm{~S}$ in the air from the reduction of sulphur compound present in waste [24].

In the absence of free oxygen, reactions of organic matter degradation begin by the intervention of anaerobic bacteria using nitrates as a source of $\mathrm{O}_{2}$ and then by the sulfatereducing anaerobic bacteria using sulphates as source of $\mathrm{O}_{2}$. In ultimate stage, the degradation takes place by methanogenic bacteria that produce methane from the $\mathrm{CO}_{2}$ reduction or by attacking acetates or methanol, which explain the unpleasant smells that are expressed at the shores of the effluents [25].

In the effluents of important agglomerations of the Moroccan Mediterranean coast with industrial activity (Tangier, Tétouan and Nador), the ratio $\mathrm{COD} / \mathrm{BOD}$ are higher than 2.5, thus reflecting industrial predominance in discharges. Generally speaking, the contribution of industry in wastewaters discharged from coastal cities is estimated to be about 55\% [26]. This ratio indicates the importance of polluting material considered as little biodegradable or even non-biodegradable $[12,27]$. The wastewater presents then an industrial predominance character and thus not easily biodegradable. Reflecting the ability of the organic substances bio-deterioration by the micro-organisms of the watery system [28], COD/BOD ratios indicate the weak conservation of the biological balance of the natural ecosystem against urban wastewater.

Water effluents were highly loaded with hydrocarbons. The $1 \mathrm{mg} / \mathrm{L}$ standard limit is largely exceeded for all studied sites. The flows drained to the Moroccan Mediterranean coasts are considerably higher and reach $2.65 \mathrm{~kg} / \mathrm{d}$ in Tangier harbour. The total hydrocarbons spilled in coast is estimated at more than $5.15 \mathrm{~kg} / \mathrm{d}$, if we count the many small harbours, fishing villages and small villages that line the coast. Moreover, sediments are known to act as a pollution reservoir, playing a fundamental role in the geochemical cycle of all chemical elements [29]. The results obtained showed amounts ranging from 850 to $5280 \mu \mathrm{g} / \mathrm{g}$, representing 3.95 to $50 \%$ of TOC and exceed the quantities usually extracted from immature recent sediments which are in general $3 \%$ of TOC at maximum, corresponding to free hydrocarbons inherited from original biomass [30]. This situation reflected the contamination of studied sites by allochthonous hydrocarbons corresponding to pollution products resulting from industrial units. The qualitative analysis confirmed the petroleum hydrocarbon compounds origin. The composition of extracted hydrocarbon from effluent is dominated by the polar products fraction. The light hydrocarbons migrate more easily, at the expense of the polar compounds which, thanks to their functional groupings, remain attached to the mineral matrix by adsorption $[31,32]$. Samples taken from Moroccan Mediterranean coasts, showed hydrocarbon composition dominated by the light compounds fraction which could reach up to $70 \%$ [33].

Indeed, the rates of hydrocarbons identified in superficial sediments samples, water and benthic organisms endowed with remarkable ability to filter, coming from different sites of the Mediterranean Moroccan coasts (Tangier - Nador), showing important levels of contamination $[34,35]$. The Tangier, Tetouan and Nador coastal area represent the most exposed zones to urban and industrial discharges. The recorded contamination rates, corresponding to non aromatic hydrocarbons (NAH) and polyaromatic hydrocarbons (PAH) are largely higher than the allowed standards.

In the case of Tangier's bay, coastal area of Ksar Sghir and Martil and Nador lagoon, hydrocarbons rates were respectively $62.5,10,31.5$ and $48 \mu \mathrm{g} / \mathrm{L}$. Organisms showed THC rates varying from 1137.5 in Ksar Sghir to 3087.5 in Tangier's bay. In sediments, the THC varied from 244 recorded in Ksar Sghir to $3754 \mu \mathrm{g} / \mathrm{L}$ observed in the Martil coast. NAH analysis revealed a relationship between hydrocarbons detected in the effluents and those detected in coastal marine waters. This link was reflected in the chromatograms of NAH. All chromatograms showed the same characteristics: an unimodal distribution of n-alkanes dominated by heavy compounds and the presence of the Unressolved Compound Mixture named UCM which generally contains ramified and cyclic hydrocarbons. This UCM appear in all samples shifted towards the heavy compounds. This fact was often related to petrogenic origins (Fig. $4 a, b$ and $\mathbf{c}$ ).

The analysis of the F2 fraction (PAH) revealed the presence of high concentrations. Twelve PAH were identified. The most represented compounds correspond to anthracene and triphenyl-methane. These compounds are mostly phenyl groups derived from anthropogenic hydrocarbons (industrial activities) [33].

On the other hand, linear alkylbenzens (LABs), containing alkyl chain ranging from 13 to 14 carbons, were detected in cockles from sampled sites of North-Western Moroccan Mediterranean coasts analyzed by monitoring the key ion at $\mathrm{m} / \mathrm{z} 91$ and $\mathrm{m} / \mathrm{z} 105$. Total concentrations of LABs vary from 478 to $1954 \mathrm{ng} / \mathrm{g} \mathrm{dw}$ [36]. Long chain alkylbenzenes are very important intermediates in the manufacture of the detergents surfactants [37], and they are the raw material for the industrial production of the linear alkylbenzenesulfonates 

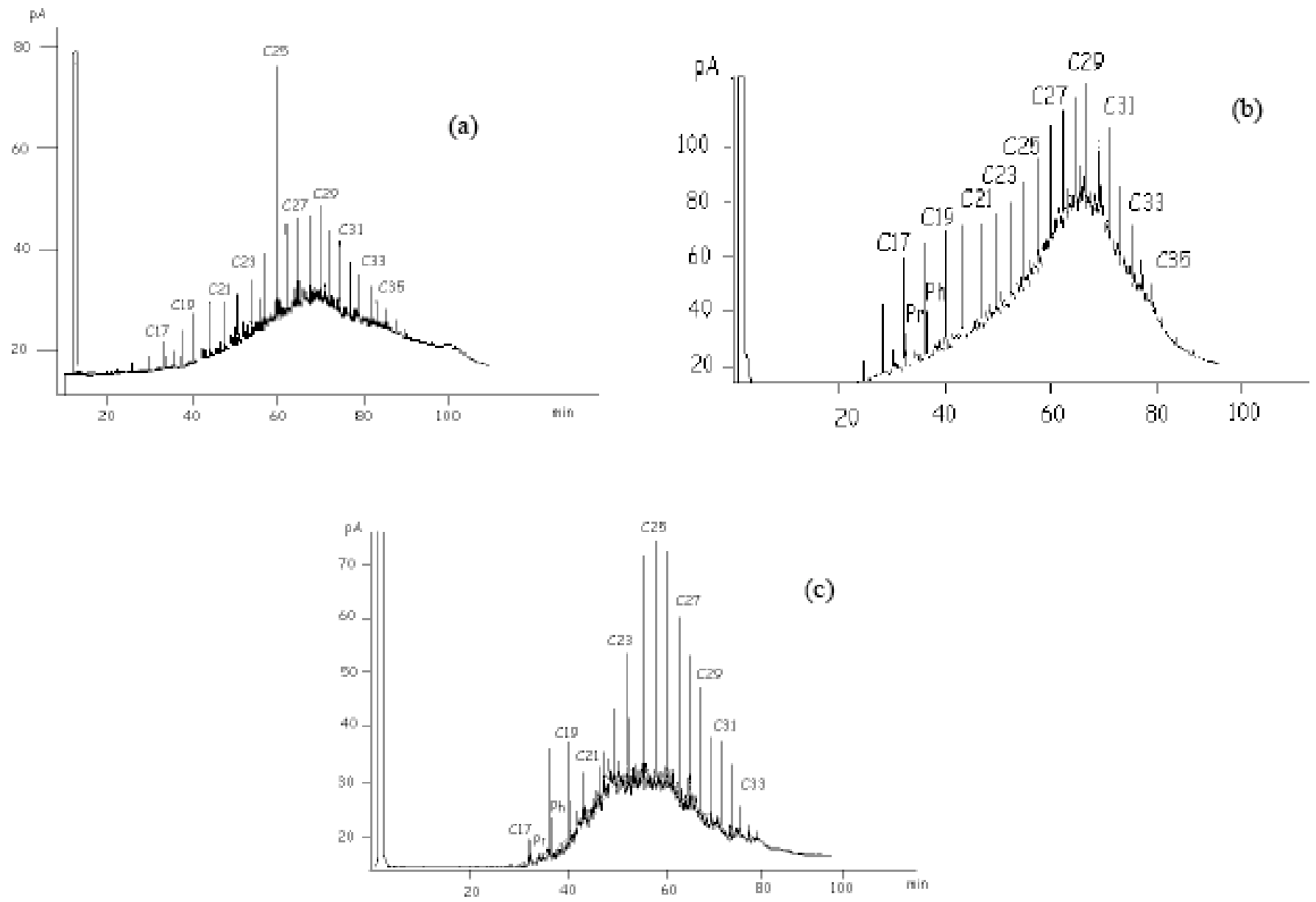

Fig. (4). Gas chromatogram of aliphatic and alicyclic hydrocarbons from sediment sampled from (a) Oued Mghogha (mouth), (b) Tangier's Bay and (c) Oued Laou (mouth). n-Alkanes are designated as C17-C35; Pr: pristine; Ph: phytane; UCM: unresolved complex mixture.

(LAS) which are the anionic surfactants commonly used in domestic synthetic detergents [38-40]. More resistant to the microbial degradation, LABs have been widely used for monitoring sewage inputs [40, 41]. They were detected in water $[40,42]$, in river and marine sediments $[43,44]$ and in marine organisms $[39,45]$ and thus reflect the urban origin of at least part of the hydrocarbons found.

The spatial distribution of hydrocarbons revealed a strong relation between contamination levels and the effects of anthropogenic pressures on the coastline. Indeed, this distribution was strongly linked to the proximity to domestic and industrial effluents, to harbour activities (fishing and navigation) and to intense maritime traffic. The impact of this latter was clearly shown on the rocks of the Ksar Sghir site, where it is remarkable an important tarry deposit [34]. The qualitative and quantitative analysis point out two important origins of hydrocarbons: natural source linked to phytoplankton, bacteria and continental plants and anthropogenic source related to petrogenic inputs from harbours and fishing activities and urban dismissals emanating from coastal agglomerations [33].

Heavy metals are among most important chemical substances that may degrade water quality. In aquatic ecosystems, the concentrations of these heavy metals depend on suspended matter content. However, drained SS to coasts are important in quantity, representing more than $232 \mathrm{t} / \mathrm{d}$, and they represent and important source of metals, its final chemical form and bioavailability being dependent on water $\mathrm{pH}$ [46].

Metal pollution was also important in the zone and, mainly as high concentrations of lead, cadmium, chromium and nickel that, in some places, exceeded the permitted levels. Draining flows to the coast were estimated to be $23.15 \mathrm{~kg} / \mathrm{d}$ for $\mathrm{Pb}, 12.65 \mathrm{~kg} / \mathrm{d}$ for $\mathrm{Cd}, 10.85 \mathrm{~kg} / \mathrm{d}$ for $\mathrm{Cr}$ and $17.45 \mathrm{~kg} / \mathrm{d}$ for Ni. For $\mathrm{Cu}$ and $\mathrm{Zn}$, estimated flows were 21.50 and $47.50 \mathrm{~kg} / \mathrm{d}$ respectively. These heavy metals, transported to the marine environment, come from natural and anthropogenic sources, discharged from effluents, leaching of metals coming from discharges and solid waste, inputs from rural areas (pesticides) or atmospheric sources (fuel combustion).

The statistical analysis showed significant correlation between $\mathrm{SS}$, and $\mathrm{Cu}, \mathrm{Zn}, \mathrm{Cr}, \mathrm{Ni}, \mathrm{MO}$ and, at lesser extent, $\mathrm{Pb}$. The correlation coefficients fluctuated from 0.743 to 0.852 . On the other hand, there was also a significant correlation between $\mathrm{OM}$ and $\mathrm{Cd}$. The hydrocarbons are a special

case (Table 6), suggesting different anthropogenic origins. Multivariate analysis using PCA showed a dispersion of different parameters for some areas except Martil and Mghogha sites and, at lesser extent, Souani site which form the same group with metals, hydrocarbons, suspended solids 
Table 6. Correlation Matrix of the Various Measured Parameters

\begin{tabular}{|c|c|c|c|c|c|c|c|c|c|}
\hline & SS & OM & HC & $\mathbf{P b}$ & $\mathrm{Cu}$ & $\mathbf{Z n}$ & Cd & $\mathrm{Cr}$ & $\mathbf{N i}$ \\
\hline SS & 1.000 & & & & & & & & \\
\hline $\mathrm{HC}$ & -0.036 & 0.252 & 1.000 & & & & & & \\
\hline $\mathbf{P b}$ & 0.571 & 0.611 & 0.107 & 1.000 & & & & & \\
\hline $\mathbf{Z n}$ & 0.743 & 0.633 & 0.270 & 0.204 & 0.850 & 1.000 & & & \\
\hline Cd & 0.156 & 0.719 & 0.143 & 0.857 & 0.252 & -0.024 & 1.000 & & \\
\hline $\mathrm{Cr}$ & 0.852 & 0.618 & -0.290 & 0.704 & 0.927 & 0.691 & 0.519 & 1.000 & \\
\hline $\mathbf{N i}$ & 0.826 & 0.669 & 0.234 & 0.407 & 0.945 & 0.795 & 0.241 & 0.898 & 1.000 \\
\hline
\end{tabular}

and oxydable matters (Fig. 3). This fact explains that Tangier and Tetouan areas are hot pollution spots of the Moroccan Mediterranean coastline. This is in agreement with a study on the assessment of metal contamination in waters of Tangier bay performed by Stitou et al., who reported $\mathrm{Fe}, \mathrm{Cu}$, $\mathrm{Pb}$ and $\mathrm{Ni}$ rates representing a metal anthropogenic pollution resulting from industrial discharges of Mghogha river and especially of the area of Tangier harbour [47].

As can be seen, if compared with the typical composition of wastewater $[9,11]$, the various analyzed parameters in many studied effluents show, generally, largely higher contents (Table 7).

In comparison with other Moroccan cities, effluents from El Jadida and Azemour, located on the Moroccan Atlantic coast, are loaded with pollutants. CDO is $4194 \mathrm{mg} / \mathrm{L}$ and the dissolved oxygen rates are $3 \mathrm{mg} / \mathrm{L}$ on average [48] while SS are $785 \mathrm{mg} / \mathrm{L}$. In Jorf Lasfar region (Atlantic coast of Morocco), the analysis of heavy metals from tissues of two Polychaetes species, Sabellaria alveolata and Arenicola grubii, collected from a polluted site, showed an anthropogenic bioaccumulation of metals $(\mathrm{Cd}, \mathrm{Zn}, \mathrm{Cu}, \mathrm{Fe}, \mathrm{Al}, \mathrm{Cr}$ and $\mathrm{Mn}$ ) originated from urban wastewater. In Fez region (Morocco), particularly in Fez and Sebou rivers, water quality assessment based on the physicochemical and ecotoxicological investigations has indicated that sites located close to the most urbanized and industrialized areas are severely polluted. The major water quality problems are: low dissolved oxygen (DO), high turbidity, organic matter and ammonia contents, severe chromium and copper pollution and high acute and chronic toxicity [49]. Water samples and samples of suspended solids were collected along Sebou river and its tributaries. Analysis results of both dissolved and particle phase constituents revealed high levels pollution of $\mathrm{Cu}(0.25 \mathrm{mg} / \mathrm{L}$ dissolved $\mathrm{Cu}, 0.55 \mathrm{mg} / \mathrm{g}$ particulate $\mathrm{Cu}), \mathrm{Pb}(0.23 \mathrm{mg} / \mathrm{L}, 0.35 \mathrm{mg} / \mathrm{g}), \mathrm{Fe}(27 \mathrm{mg} / \mathrm{L}, 50$ $\mathrm{mg} / \mathrm{g})$ and $\mathrm{Mn}(2.5 \mathrm{mg} / \mathrm{L}, 1 \mathrm{mg} / \mathrm{g})$. These results drew attention to the significant input from man-made sources (industry, farming, landfills) [50].

In other Mediterranean countries, such as Algeria, marine water is also currently affected by intense pollution due to industrial, urban and agricultural wastes. The western coast of Algeria (Arzew bay) is highly polluted by suspended matter, oxydable matter and hydrocarbons, with concentrations exceeding 30, 1000 and $75 \mathrm{mg} / \mathrm{L}$, respectively. Besides, wastewaters rejected in the coasts contain also some heavy metals $(\mathrm{Fe}, \mathrm{Pb}, \mathrm{Cd}, \mathrm{Zn}, \mathrm{Cu} . .$.$) [51]. The Oran coast is$ highly-coveted coastal system, where several forms of Posidonia degradation are reported: the stability of the coastline and several marine species are threatened [52]. The Algiers area is very urbanized and industrialized. Indeed, its population constitutes $17 \%$ of total Algerian population. On the other hand, this area represents $23 \%$ of industrial and economic activities. All urban and industrial wastewaters of this area are discharged without previous treatment, into Algiers Bay which is considered as highly contaminated environment. Algiers Bays is going through serious environmental problems. The spatial interpretation by geostatistical methods shows the discharges influence on the heavy metals, hydrocarbons and nutrients distribution [53].

The Sfax coastline is another very important industrial and harbour activity site which generates multiple rejections discharged in the littoral and weakens consequently the ecosystem. High contents of trace metals $(\mathrm{Cd}, \mathrm{Cr}, \mathrm{Cu}$ and $\mathrm{Pb}$ ) are recorded in the superficial layer of sediment [54].

Table 7. Concentrations of Pollutants in Domestic and Urban Wastewater

\begin{tabular}{|c|c|c|c|c|c|c|c|c|c|c|c|c|}
\hline & & SS & BOD & COD & $\mathrm{Cl}^{-}$ & $\mathrm{SO}_{4}{ }^{2-}$ & $\mathrm{NO}_{3}^{-}$ & $\mathrm{NO}_{2}^{-}$ & $\mathbf{C d}$ & $\mathrm{Cu}$ & $\mathbf{P b}$ & $\mathbf{Z n}$ \\
\hline \multirow{2}{*}{$\begin{array}{c}\text { Domestic Wastewater } \\
{[9]}\end{array}$} & Weak value & 100 & 110 & 250 & 30 & 20 & 0 & 0 & - & - & - & - \\
\hline & Strong value & 350 & 400 & 1000 & 100 & 50 & 0 & 0 & - & - & - & - \\
\hline Urban Wastewater [11] & & $100-500$ & $100-400$ & $250-1000$ & - & - & - & - & $1-10$ & $83-100$ & $5-78$ & $100-570$ \\
\hline
\end{tabular}


The estimation of hydrocarbon pollution along Sfax and Gabès Gulf coasts (Tunisia), shows that the non-aromatic hydrocarbon concentrations vary in the range of 310-1406 $\mu \mathrm{g} / \mathrm{g}$ sediments in dry weight, which is high compared to other Mediterranean sites. GC/MS data indicate a large group of unresolved compounds suggesting a petroleum contamination [55].

Against this serious situation related to organic and mineral contamination of the Moroccan and other Mediterranean coastlines, local authorities have opted for the installation of treatment plants, with different results. At Tangier, this action against pollution is a drawdown rate of $30 \%$ of organic load, but still remains insufficient. The treated water is discharged toward the sea via a $3 \mathrm{~km}$ submarine emissary outfall. The discharged water is still loaded with various contaminants (hydrocarbons, heavy metals and toxic elements). The sea self-purification, whereupon the authorities count for an additional treatment, cannot be sufficient. The wastewater treatment plant of Grand Nador, which is the largest on the south shore of the Mediterranean in terms of size and advanced used technology, is the second of its kind after that of Al Hoceima. These both stations assure a high and better performance than Tangier.

In parallel, Morocco is trying to implement gradually, in the framework of its national legislation, its international commitments on bilateral, multilateral and regional levels. This effort is further required that these engagements have involved the participation in specific programs, particularly in the Mediterranean. These programs often result into the targeted resolutions or recommendations implementation to complete a rigorous policy of sustainable marine and coastal environment development. International cooperation is an essential support and legal and moral obligation which is reflected through the ratification of international conventions and agreements of which seven are specific to the Mediterranean. The emphasis should be on Morocco's accession to the Barcelona Convention which states, in its 81/420/EEC of 19 May 1981 Decision, the fight against marine pollution by hydrocarbons, telluric and other harmful substances in cases of emergency. As defined by the Barcelona Convention, Morocco has established a coastal monitoring network, which aims mainly to coastal areas safety.

\section{CONCLUSIONS}

The physicochemical, biochemical and geochemical analysis, achieved in all harbors and effluents, revealed that pollution is reaching critical levels. Unfortunately, wastewaters are transported to the coast through numerous rivers and rejected in sea through rivers mouths, without effective preliminary treatment or with inadequate treatment. Wastewaters drained toward the coast are highly loaded with SS important quantities of organic matter. Biochemical oxygen demand and chemical oxygen demand reach $13.65 \mathrm{t} / \mathrm{d}$ and $50.15 \mathrm{t} / \mathrm{d}$ respectively, exceeding extremely the allowable

limits and reflecting industrial predominance discharges. The total oxydable matters drained to the sea, expressed in terms of BOD and CDO amounts, exceed $100 \mathrm{t} / \mathrm{d}$. Also, the dissolved oxygen rates are low and fluctuate between 0 and
$2.95 \mathrm{mg} / \mathrm{L}$, except for some rivers. This reflects a tendency of different areas to anoxia.

Total hydrocarbons spilled in coast is estimated to be above $5.15 \mathrm{t} / \mathrm{d}$, if we count the several small ports, fishing villages and small villages that line the coast. Metal pollution was also important in the zone, with very high concentrations of several metals such as lead, cadmium, chromium and nickel, exceeding the values admitted by authorities in several sites. Flux drained toward the coast was estimated to be $23.15 \mathrm{~kg} / \mathrm{d}$ for $\mathrm{Pb}, 12.65 \mathrm{~kg} / \mathrm{d}$ for $\mathrm{Cd}, 10.85 \mathrm{~kg} / \mathrm{d}$ for $\mathrm{Cr}$ and $17.45 \mathrm{~kg} / \mathrm{d}$ for $\mathrm{Ni}$. For $\mathrm{Cu}$ and $\mathrm{Zn}$, estimated flows were 21.50 and $47.50 \mathrm{~kg} / \mathrm{d}$ respectively. This indicates the presence of hot spots of the Moroccan Mediterranean coastline under the high anthropic pressure. These zones present natural characteristics that permit the accumulation of pollutants as a result of low capacity of assimilation due to the nature of the semi closed system and has several bays characterized by shallow depth water.

To face this serious situation related to organic and mineral contamination of the Moroccan Mediterranean coastline, more efforts are still required, particularly from local and governmental authorities dealing with environment to preserve healthy marine environment.

\section{CONFLICT OF INTEREST}

None declared.

\section{ACKNOWLEDGEMENT}

None declared.

\section{REFERENCES}

[1] Sumok P. Riverwater quality monitoring: sharing Sarawak experience. In: Proc. 6th Sabah Inter-Agency Tropical Ecosystem (SITE) Research Seminar; Kota Kinabalu: Malaysia 2001; p. 4.

[2] Phiri O, Mumba P, Moyo BHZ, Kadewa W. Assessment of the impact of industrial effluents on water quality of receiving rivers in urban areas of Malawi. Int J Environ Sci Technol 2005; 2: 237-44.

[3] Burns KA, Saliot A. Petroleum hydrocarbons in the Mediterranean Sea: a mass balance. Mar Chem 1986; 20: 141-57.

[4] Hopkins TS. Physical processes in the Mediterranean basins. In: Kjerfve B, Ed. Estuarine transport processes. South Carolina, Columbia: University of South Caroline Press 1978; pp. 269-310.

[5] UNEP. Les perspectives du Plan Bleu sur l'environnement et le développement : Prospective 2025 pour un développement durable du bassin méditerranéen, Rapport. Programme des Nations Unies pour l'Environnement 2005; p. 427.

[6] Bilardo U, Mereddu G, Eds. La pollution par hydrocarbures dans la mer Méditerranée in trafic pétrolier et environnement durable, Clean up the Med 2007.

[7] Belcaid S. Biodiversité dans la zone maritime détroit de Gibraltar et Méditerranée occidentale, Journée mondiale de la terre, tanger 2010.

[8] CSEC. Eds. Réutilisation des eaux usées en agriculture. Conseil Supérieur de l'eau et du climat, Rabat, Maroc 1994; p. 88.

[9] Metcalf and Eddy. Wastewater engineering. Treatment disposal reuse. Tchobanoglous G, Burton FL. Eds. New York: McGraw-Hill Publishers 1991; p. 1820.

[10] Bouzid S, Andaloussi H, Aboumaria K, Er-Raioui H. Urban effluent pollution from the Mghogha flow of the west, margin of the Mediterranean Sea, Morocco. Afr J Environ Sci Technol 2008; 2: 116-23. 
[11] Grommaire-Mertz MC. La pollution des eaux pluviales urbaines en réseau d'assainissement unitaire, Caractéristiques et origines. Thèse de doctorat de l'Ecole nationale de ponts et chaussées 1998; p. 477.

[12] Rodier J, Ed. L'analyse de l'eau: eaux naturelles, eaux résiduaires, eau de mer: physico-chimie, bactériologie et biologie. Paris, France: Dunod 1996; p. 1383.

[13] Blinda M. Pollution tellurique du littoral nord-ouest du Maroc entre Tanger et Tétouan: Caractérisation, Impact sur l'Environnement et Proposition de Solutions, thèse de doctorat, Université Mohammed V- Rabat (Maroc) 2007; p. 162.

[14] Bloundi K. Etude géochimique de la lagune de Nador (Maroc oriental): Impacts des facteurs anthropiques, thèse de doctorat, Thèse en cotutelle Ecole et Observatoire des Sciences de la Terre Centre de Géochimie de la Surface (UMR 7517) (France) et Université Mohamed V- Agdal (Maroc) 2005; p. 198.

[15] Ministere de I'Environment du Maroc. Eds. Normes marocaines. Bulletin officiel du Maroc (5062 du 30 ramadan 1423). Ministère de l'Aménagement du Territoire, de l'Eau et de l'Environnement. Rabat 2002.

[16] Nisbet Verneaux J. Composantes chimiques des eaux courantes. Discussion et proposition de classes entant que bases d'interprétation des analyses chimiques. Ann Limnol 1970; 6: 1619.

[17] Ericksson E, Auffarth K, Henze M, Ledin A. Characteristics of grey wastewater. Urban Water 2002; 4: 85-104.

[18] Gray SR, Becker NSC. Contaminant flows in urban residential water systems. Urban Water 2002; 4: 331-46.

[19] Dyer SD, Peng C, Mcavoy DC, et al. The influence of untreated wastewater to aquatic communities in the balatuim river, the Philippines, Pergamon. Chemosphere 2003; 52: 43-53.

[20] Waksman SA. Humus, origin, chemical composition and importance in nature. Baltimore: Williams and Wilkins Co. 1938; p. 526.

[21] EL Hatimi I, Achab M, EL Moumni B. Impact des émissaires et canalisation sur l'environnement de la baie de Tanger (Maroc): approche géochimique. Bulletin de l'Institut scientifique, Rabat. Sec Sci de la Terre 2002; 24: 49-58.

[22] Manskaya SM, Drozdova TV. Geochemistry of organic substances. Shapiro L, Breger IA, Eds. Oxford: Pergamon Press 1968; p. 345.

[23] Rashid MA, Leonard JD. Modifications in the solubility and precipitation behaviour of various metals as a result of their interaction with sedimentary humic acids. Chem Geol 1973; 11: 89-97.

[24] Thomas O. Ed. Métrologie des eaux résiduaires. Cebedoc Lavoisier/Tec et Doc 11 Liège -Paris 1995; p. 192.

[25] Berner R. Sedimentary pyrite formation: an update. Geochim. Cosmochim Acta 1984; 48 (4): 605-15.

[26] Benkhokroun M, Bouchama $M$. La réutilisation des eaux usées en agriculture au Maroc. In: VII congrée mondial des ressources en eau, gestion des ressources en eau, Rabat 1993; pp. 13-18.

[27] Henze M, Harremoes P, La Cour Jansen J, Arvin E, Eds. Wastewater treatment. Biological and chemical processes. Berlin: Springer Verlag 1997; pp. 143-92.

[28] Sponza DT. Application of toxicity tests into discharges of the pulp-paper industry in Turkey. Ecotox Environm Safe 2003; 54: 74-86.

[29] Luoma SN. Bioavailability of trace metals to aquatic organisms. A review. Sci Total Environ 1983; 28: 1-22.

[30] Tissot B, Welte DH, Eds. Petroleum formation and occurence, a new approach to oil and gaz exploration. Berlin: Springer Verlag 1978; p. 538.

[31] Tissot BP, Pelet R, Roucaché J, Combaz A. Utilisation des alcanes comme fossiles géochimiques indicateurs des environnement géologiques. In: Campos R, Goni J, Eds. Advances in Organic Geochemistry. Madrid España: Enadimsa 1975; pp. 117-54.

[32] Welte DH. Petroleum exploration and organic geochemistry. J Geochem Explor 1972; 1: 117-36.

[33] Er-Raioui H, Bouzid S, Marhraoui M, Saliot A. Hydrocarbon pollution of the Mediterranean coastline of Morocco. Ocean Coast Manage 2009; 52: 124-9.
[34] Bouzid S, Er-Raioui H, Saliot A, Bouloubassi I, Marhraoui M. International Congess of Biochemistry. Contamination de la frange littorale de Tétouan par les hydrocarbures. Agadir 2006.

[35] Bouzid S. Etat de la contamination des côtes ouest de la mediterrannee par les hydrocarbures / baie de Tanger et frange littorale «fnideq-kaâ srass», thèse de doctorat, Université Abdelmalek Essâadi (Maroc), 2007; p. 167.

[36] Bouzid S, Khannous S, Bouloubassi I, Saliot A, Er-Raioui H. Assessment of the Mediterranean Moroccan coasts contamination by hydrocarbons (NAH, AH and Alkylbenzenes). Int J Geosci 2011 (in press).

[37] Desmukh ARAS, Gumaste VK, Bhawal BM. Alkilation of bnzene with long chain (C8-C18) linear primary alcohols over zeolite-Y. Cata Letters 2000; 64 (2-4): 247-50.

[38] Medeiros PM, Bicego MC, Castelao RM, et al. Natural and anthropogenic hydrocarbon inputs to sediments of Patos Lagoon Estuary, Brazil. Envirom Int 2005; 31 (1): 77-87.

[39] Tsutsumi S, Yamaguchi Y, Nishida I, et al. Alkylbenzenes in mussels from South and South East Asian coasts as a molecular tool to assess sewage impact. Mar Poll Bul 2002; 45 (1): 325-31.

[40] Isobe KO, Zakaria MP, Chiem NH, et al. Distribution of linear alkylbenzenes (LABs) in riverine and coastal environments in South and Southeast Asia. Water Res 2004; 38 (9): 2449-59.

[41] Takada H, Ishiwatari R. Linear alkylbenzenes in urban riverine environments in Tokyo: distribution, source, and behavior. Environ Sci Technol 1987; 21 (9): 875-83.

[42] Crisp PT, Brenner S, Venkatesan MI, et al. Organic chemical characterization of sediment-trap particles from San Nicolas, Santa Barbara, Santa Monica and San Pedro Basins, California. Geochim. Cosmochim Acta 1979; 43 (11): 1791-801.

[43] Takada H, Ogura N, Ishiwatari R. Distribution of linear alkylbenzenes (LABs) and linear alkylbenzene sulfonates (LAS) in Tokyo Bay sediments. Estuarine Coast Shelf Sci 1992; 35 (2): 14156.

[44] Chalaux N, Takada H, Bayona JM. Molecular markers in Tokyo Bay sediments: sources and distribution. Mar Envir Res 1995; 40 (1): 77-92.

[45] Serrazanetti GP, Pagnucco C, Conte LS, Artusi R. Aliphatic hydrocarbons and linear alkylbenzenes in zooplankton from the Gulf of Trieste. Chemosphere 1994; 28 (6): 1119-26.

[46] Bordin G. Distribution et évolution saisonnière du cuivre dissous dans un écosystème estuarien macrotidal d'Europe occidentale (estuaire de l'Aulne, France). Oceanologica Acta 1991; 14: 445-56.

[47] Stitou M, Dolores Galindo M, El Mai H, et al. Etude relative à l'évaluation de la contamination métallique dans la plage de la ville de Tanger, Les cahiers de la recherche de l'Université Abdelmalek Essaadi 2010; 1 (4-5): 39-48

[48] Kaimoussi A. Etude de la variabilité de l'accumulation des métaux lourds dans les différents compartiments (sec, mollisque et algue) du littoral de la région d'El Jadida, thèse de doctorat, université Chouaib Doukhali, El Jadida, Maroc 1996; p. 138.

[49] Koukal B, Dominik J, Vignati D, et al. Assessment of water quality and toxicity of polluted Rivers Fez and Sebou in the region of Fez (Morocco). Environ Poll 2004; 131: 163-72.

[50] Azzaoui S, El Hanbali M, Leblanc M. Copper, lead, iron and manganese in the Sebou drainage basin: sources and impact on surface water quality. Water Qual Res J 2002; 37 (4): 773-84.

[51] Baghdad K, Bendraoua A. Traitement, étude, impact des effluents liquides sur le littoral de l'Ouest algerien. 2ème colloque international «Biodiversité et Ecosystèmes littoraux», Oran, Algeria 2010; pp. 353-7.

[52] Kais BH, Bouras D, Boutiba Z. Surveillance et évaluation de la qualité de la biodiversité des milieux et des habitats côtiers (côte oranaise, Algérie nord occidentale). 2ème colloque international «Biodiversité et Ecosystèmes littoraux », Oran, Algeria 2010; p. 61.

[53] Mennad M, Bachari NEI. Approche SIG pour l'analyse spacialte de la pollution marine dans la baie d'Alger. 2ème colloque international «Biodiversité et Ecosystèmes littoraux », Oran, Algeria 2010; p. 59.

[54] Illou S. Impacts des rejets telluriques d'origines domestique et industrielle sur les environnements côtiers : cas du littoral Nord de la ville de Sfax (Tunisie), Thèse de doctorat, Université de Tunis II (Tunisie), 1999; p. 259. 
[55] Zaghden H, Kallel M, Louati A, Elleuch B, Oudot J, Saliot A.

(Tunisia) Mediterrranean Sea. Mar Poll Bul 2005; 50: 1287-94. Hydrocarbons in surface sediments from the Sfax coastal zone

Received: May 26, 2011

Revised: July 1, 2011

Accepted: July 8, 2011

(c) Er-Raioui et al.; Licensee Bentham Open.

This is an open access article licensed under the terms of the Creative Commons Attribution Non-Commercial License (http://creativecommons.org/licenses/by$\mathrm{nc} / 3.0 /$ ), which permits unrestricted, non-commercial use, distribution and reproduction in any medium, provided the work is properly cited. 